\title{
The fallible inflexibility of bernard spilsbury: a charismatic doctor and his discontents
}

\section{Commentary}

Modern forensic science owes a great deal to Sir Bernard Spilsbury. Commencing with the Crippen case in 1910, he became the public face of forensic medicine - the 'people's pathologist ${ }^{1}$ providing credibility to a field that had been deeply distrusted - the Beastly Science ${ }^{2}$ - and began the modern cult of forensic pathology. ${ }^{3}$ As an innovator, Spilsbury could not be equalled. He was the first to come up with idea of the Murder Bag containing the essential tools for the forensic doctor to take to the scene of the crime. He made good use of the available science and was prepared to experiment, showing how George Smith drowned his victims in the "Brides in the Bath Murders". ${ }^{4}$ Preparing evidence for the case was one thing; it was in court that Spilsbury came into his own. Tall, handsome and impeccably dressed with a top hat and flower in his lapel, he conveyed an aura of impressive rectitude, one that defence lawyers were seldom able to penetrate. In giving his evidence, Spilsbury spoke directly to the jury in commonplace language, avoiding the technical jargon used by specialists who came across as pompous and patronising.

Spilsbury, who had no doubt about his ability, referred to himself as God's locum. ${ }^{5}$ As Richard Gordon put it, "His opinions were so impregnable, he could achieve single-handed all the legal consequences of a homicide - arrest, prosecution, conviction, and final post-mortem - requiring only the brief assistance of the hangman". 6 With every sensational murder, the papers only had to run the headline "Spilsbury called in" for the public to decide that the defendant was as good as dangling from the hangman's rope. ${ }^{7}$ Prosecutors and judges were in awe of Spilsbury; defence lawyers, not always the leading lights of the field, were intimidated and failed to challenge his emphatic assertions. ${ }^{8}$ Herein lay the problem. Spilsbury was deeply dogmatic and refused to ever shift or acknowledge that there could be other explanations, even less concede that he could be wrong. His certitude was appealing to juries, as opposed to other medical experts who cautiously hedged their statements. But this was to conceal a deep problem that had extreme consequences at a time when capital punishment was mandatory for murder convictions. In the decades that followed his death (by suicide) in 1947, his reputation has undergone a severe revision. Over a long career, Spilsbury's evidence is believed to have to have led to at least two unjust executions, with several more questionable convictions.

Analysis of the disputed cases reveal a disturbing pattern. Spilsbury's determinations hardened into the adamantine belief that he could not be wrong, relying less and less on firm evidence rather than his intuition. What brought Spilsbury undone was the rise of a new generation of forensic doctors who were not intimidated by his reputation and prepared to challenge him on every point; prominent among these were Sydney Smith, Keith Simpson and Francis Camps. ${ }^{9}$ First lawyers, then judges and juries, no longer took him at his word. ${ }^{10}$ The aura gone, there was nothing left. By the end of his career, Spilsbury was reduced to hanging around the coroner's office in the hope of picking up an overdose or surgical death for autopsy. The case of Bernard Spilsbury is an object lesson of the pitfalls in forensic medicine. It epitomises the dangers of the charismatic doctor,

\author{
Volume 4 Issue 2 - 2017
}

\author{
Robert M Kaplan \\ Graduate School of Medicine, University of Wollongong, \\ Australia
}

Correspondence: Robert M Kaplan, Graduate School of Medicine, University of Wollongong, PO Box 316, Thirroul, NSW 25I5, Australia, Tel (+6I) 242683949 , Email rob@rmkaplan.com.au

Received: January 18, 2017| Published: March 07, 2017

a problem as old as medicine and one likely to continue in future. Charismatic doctors combine features of the state defined by the Apostle Paul and, more recently, sociologist Max Weber. They are believed by their patients to have a god-given ability that transcends the mundane qualities of their colleagues who are bound by the material nature of disease and the inexorable fact that death comes to all, one way or another. ${ }^{11}$ Charismatic doctors are often highly talented and easily ascend to leadership in their field. They get miraculous results and develop a fanatical following. Here arises the problem.

It is inevitable that these doctors attain an exalted view of their abilities, best described as a demiurge syndrome. ${ }^{12}$ The outcome can easily be lethal; when followers remain demanding of perfect outcomes, the doctor goes on to ever greater extremes. Their practice hardens into a fanatic determination to follow the special path and any casualties on the way explained as due to failure of the patient - in reality, a failure of faith, a concept familiar to prophets, cult leaders and gurus. The history of medicine is littered with such individuals. A few notable examples are Christian Barnard, Jacques Lacan, Leander Starr Jameson, ${ }^{13}$ and Ernst Schweninger. Barnard, who did the world's first heart transplant, pushed the edges of the ethical envelope. ${ }^{14}$ Obsessed with remaining in front, he became increasingly reckless with his operations and was likely to be stood down if he hadn't moved on to other things. Lacan, the French psychiatrist and psychoanalyst charismatic figures, commencing with Freud, are especially common in this field - had a fanatic intellectual following, bewitched by the deluge of nothingness produced by his incessant logorrhoea, which to anyone believing in factual truth was simply rubbish of the highest order. ${ }^{15}$ Schweninger, little more than a charlatan, was regarded as disreputable by his colleagues but redeemed by his hold over Bismarck, the German Chancellor, who he persuaded to change his diet and lifestyle, thereby prolonging his life. ${ }^{16}$

Roy Meadow, the eminent British pediatrician, brings us back to the problems arising from Spilsbury's charismatic role. Meadow was preoccupied with Munchausen's Syndrome by Proxy (MSBP), a condition of questionable scientific validity in which women are 
alleged to deliberately harm their children to make them ill. ${ }^{17}$ From this Meadow became an expert on children who died suddenly and unexpectedly. After he interviewed their mothers, the courts uncritically accepted his diagnosis of MSBP and jailed them for murder. It took a public uproar before several convictions were overturned and Meadow was deregistered (but reinstated on appeal). ${ }^{18}$ In the Meadow case, we see all the features - and problems - of the charismatic doctor that were evident with Spilsbury. Meadow had no hesitation in venturing outside his field of expertise. Prosecutors frequently used him and he gave lectures to judges. He was not trained in adult psychiatry and it is unclear why the courts did not demur at his diagnoses of adult women. Meadow held his ideas on MSBP as a matter of faith and this was accepted by his many followers, both in and out of medicine. Most important, when it became evident that the facts were at odds with his beliefs, he refused to recant and has never expressed contrition for the miscarriages of justice that occurred.

Spilsbury's dogmatism leaves Meadow in the shade. He was utterly immovable when challenged; nothing could make him recant to the slightest degree. He detested homosexuals and had something of an obsession with illegal abortion. Without expertise in obstetrics, he made incorrect assertions that he had no right to hold. The belief in his rectitude was infinite. This started in 1910 with the Crippen case. He insisted that a tissue section on a slide could only be a hysterectomy scar, thereby proving that that the mutilated corpse (no head, limbs or genitals) was Crippen's wife Cora. ${ }^{19}$ The defence pathologists lamely responded that there was no way of proving this and it was simply a skin fold in a scar from elsewhere. All too no avail; the judge positively gushed about Spilsbury to the jury and Crippen's fate was sealed. To this day, the case continues to excite controversy. While the circumstantial evidence points to his guilt, there is no way Crippen could be found legally guilty now. Finally, the Spilsbury story illustrates the last rule of charismatic figures: when the results stop, the followers vanish. Once judges and juries began rejecting his testimony, he was effectively legal poison and no one wanted to use him any longer.

This was a tragedy in every sense. Spilsbury had been a forensic pioneer but refused to do more than teach medical students, publish few papers and never wrote the definitive textbook to pass on his expertise. The reason for this is not clear. It is possible that he feared that his ideas, when laid out in print, would be too easy to criticise. Consequently his knowledge was not passed on. His last years were miserable, by the end of the war his two sons had died and, suffering from cancer, he gassed himself in the laboratory in 1947. It must be understood that Spilsbury's evidence alone would not determine the outcome of a trial. In the adversarial system, his views would naturally be challenged. Yet, such was the infallible aura he cultivated with his dogmatic assertions that he cannot be exempted from responsibility for the miscarriages of justice that arose. The best rebuttal comes from his younger associate, Keith Simpson, who stated that it should be of no concern to the forensic witness if the accused is hanged on the basis of his evidence or if a guilty man walks free; his prime duty is to give the best evidence to the court to decide the matter. ${ }^{20}$ This was something that Spilsbury could not come to terms with, making him an object lesson in the damage can flow in the wake of charismatic doctors. His reputation has not fared well and with more evidence of his mistakes likely to emerge, can only get worse.

\section{Acknowledgments}

None.

\section{Conflicts of interest}

None.

\section{References}

1. Ramsland K. The Incomparable Witness: Sir Bernard Spilsbury. Forensic Examiner. 2008;17(1):1-70.

2. Vanezis P. Forensic medicine: past, present, and future. Lancet 2004;364(Supply 1):8-9.

3. Andrew R. Lethal witness: Sir Bernard Spilsbury honorary pathologist 2007;1-288.

4. Jane R. The Magnificent Spilsbury and the Case of the Brides in the Bath. Hachette publishing group, UK. 2010.

5. Theodore D. The expert witness, or God's locum. BMJ. 2010;340:c1384.

6. Richard G. 'Doctor Death' in Great Medical Disasters. 1983;1-87.

7. Obituary Sir Bernard Spilsbury. BMJ. 2(4538):1059.

8. Colin E. The Father of Forensics: The Groundbreaking Cases of Sir Bernard Spilsbury, and the Beginnings of Moern CSI. 2006;1-325.

9. Burney I, Pemberton N. The rise and fall of celebrity pathology. BMJ. $2010 ; 14: 341$.

10. John B. Networked Knowledge - Expert Evidence Reports Academy Of Expert Witnesses. Networked Knowledge, Australia. 2007.

11. Osmond H. God and the doctor. N Engl J Med. 1980;302(10):555-558.

12. Kaplan RM. Doctor as Demiurge. Quadrant. 2001;45(5):30-31.

13. Cornelius J. The Perils Of The 'If' Man. Frontier Partisans, USA. 2016.

14. Hoffenberg R. Christiaan Barnard: his first transplants and their impact on concepts of death. BMJ. 2001;323(7327):1478-1480.

15. Jacques L. The Shrink from Hell. The Times Higher Education. 1997;1574.

16. Haas N, Eilers J. Ernst Schweninger, Professor of Dermatology, and Bismarck's personal physician. Int J Dermatol. 2001;40(10): 662-665.

17. Kaplan R. Savonarola at the stake: the rise and fall of Roy Meadow. Australas Psychiatry. 2008;16(3):213-215.

18. Media Summary of Judgment. 2006.

19. Samuels A. Dr Crippen: innocent, or guilty but convicted by a trick? Medicine, Science and the Law. 2010;50(2):57-59.

20. Simpson K. Forty Years of Murder. 1978;1-328. 